\title{
MILYEN ESZKÖZÖKKEL JAVÍTHATÓ EGY VÁLLALAT VERSENYKÉPESSÉGE? ELEMZÉS ÉS ÖTLETEK A MÁV ZRT. SZEMÉLYSZÁLLÍTÁSI ÜZLETÁGÁNAK (SZÜ) MÜKÖDÉSE ALAPJÁN
}

A vasúti szállítás megtartásában, fejlesztésében a vasútvállalatoknak fel kell készülniük arra, hogy hatékony, lehetốleg nyereséges üzletmenetet alakítsanak ki. Ehhez tanulmányozniuk kell a vasúti folyamatokat, elemezniük kell hol, melyik tevékenységeknél keletkeznek a bevételt meghaladó költségek. Ezek után a vállalati érdek azt kívánja, hogy a veszteséges tevékenységeket szüntessék meg, szervezzék át vagy ki. A szerzô dolgozatában a magyar vasúttársaság számara néhány kitörési pontot mutat be. Természetesen nagyon sok további lehetôség is van, amelyek segíthetnének a modernizációban. Ami biztosan nem visz elôbbre, az a tétlenség, a változatlanság, a szervezet állandó átalakítása a folyamatok merevsége mellett, a hibás benchmarking.

A vasúti személyszállítás mindenütt a világon veszteséges vállalkozás. Vannak természetesen olyan megoldások, vállalatok, részterületek a közlekedés ezen ágában is, amelyek gazdaságosan, piaci körülmények között is jól prosperálnak: pl. Lettországban az áruszállítás (Gorbunows, 2003.), a franciaországi nagysebességú személyvonatok (Dumont, 2001), a nosztalgiavonatok, a svájci helyiérdekeltségú vonatok (Kaspar, 2000).

Jellemzóbb, hogy a kormányok, ill. az önkormányzatok támogatják a vasúti személyszállítást több okból is:

- szociálpolitikai célokból (minden állampolgár eljuthasson dolgozni, iskolába, egészségügyi szolgáltatókhoz, kulturális intézményekbe stb.),

- gazdasági okokból (a vasút munkatársai és családjuk élete, a vasút beszállítóinak múködése, a vasúti vállalatok fogyasztása, a szállítások stb. okán),

- környezetvédelmi szempontok miatt (a vasút a közúti szállítás foot-printjének, ökológiai lábnyomának 8\%át, a légi közlekedésének pedig 3\%-át éri el, azaz meszsze jobb náluk a környezetvédelem szempontjából),

- a hagyományok őrzése miatt (a nagy vasutas kultúrával rendelkezô országok lakói ragaszkodnak a vasúthoz, értékesebbek az ingatlanok a vasúttal rendelkezô helységekben, vasutas dinasztiák vannak, vasutas kultúr- és sportegyesületek múködnek, vasutas szakmákat oktatnak stb.), egyéb kényszerítő tényezók szorításában (pl. Magyarországon a vasút által használt állami tulajdonú területek rekultiválására nincsen felkészülve a vasútvállalat, így nem tudja leépíteni a felesleges kapacitásait). (1.ábra)

1. ábra

A személyszállitás alakulása Magyarországon 1995-2015

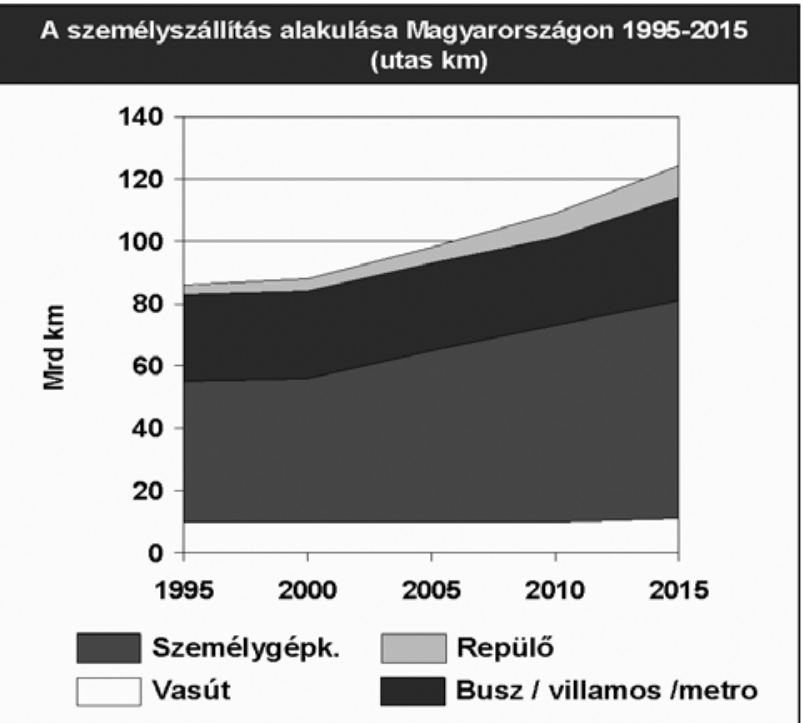


Magyarországon a legnagyobb vasútvállalat, a MÁV (Magyar Államvasutak ZRt.), a lét és a nemlét határán mozog évek óta. Felső vezetóit rendszeresen leváltja a tulajdonos (az államot képviselő kormányzat), reformok reformokat érnek, ám - alapjában - mindig minden marad a régiben. Mára az alaptốke-csökkentéssel a vállalat hitelállománya összemérhetô a vagyonával (lásd a mérlegeket a MÁV ZRt. honlapján), és a kormányzat, az EU szabályaira hivatkozva - elzárkózik minden tulajdonosi segítségnyújtástól. Ez pedig nem a korábban és ma is - legfeljebb áttételesen, némi jogi csưrcsavar után - más országokban is normális, elfogadott rendszerhez tartozó, a cég által elvárható tulajdonosi magatartás. Hiszen a versenyképesség eléréséhez szükséges egy stabil, hiteles, átfogó gazdaságpolitika, mert „,a vállalati versenyképesség nem az egyes vállalatok magánügye, hanem a nemzetgazdasági versenyképesség hordozója, megjelenési formája" (Chikán, 2006).

A kérdés: akarja-e egy ország, a világ, hogy a vasút, a vasúti személyszállítás megmaradjon? Úgy vélem, a válasz, egyelőre, egyértelmú igen. A nagytömegú, sốt egyre növekvő tömegú áruszállítás megköveteli minden közlekedési mód megtartását, ha pedig a pályák és a hozzájuk tartozó berendezések rendelkezésre állnak, akkor adódik, hogy a személyszállítást is meg kell tartani.

Másik nyomós ok a mai energiahelyzet. Amikor a fosszilis energiahordozók mennyisége záros határidó alatt lenullázódik, új energiahordozók pedig még nincsenek kitalálva sem, nemhogy ipari méretekben bevezetve, marad a villanyáram mint közlekedési energia. Pozitív tulajdonságai (könnyú, tiszta, jól szállítható, szinte bárhol felhasználható, sokféle módon és anyagból előállítható) a legrugalmasabb eszközzé teszik. Ha sikerülne a tárolását megoldani, nagyon sokáig egyeduralkodó lehetne az energiapiacon. Viszont a villanyáram - mai formájában - jól csak a kötöttpályás közlekedésben használható.

Ha elfogadjuk, hogy a vasútnak van jövője, akkor viszont vizsgálandó, hogyan lehet a mai gazdaságtalan állapotából kimozdítani. Van-e lehetôség a veszteséges üzemet átalakítani, profitábilissá tenni? Hiszen a piacon való helytálláshoz, a beruházásokhoz a versenyképesség alapfeltétel. (Chikán, 2006)

Lehet-e saját erôből, keményebb vezetôi hozzáállással, nagyobb akarattal és mersszel tenni valamit?

\section{Versenyképessé tehetốe a vasúti személyszállítás?}

Meggyőződésem, hogy igen. Erról a témáról a szakirodalomban sok tanulmány található (pl. Brown Summer, 2000.). A jelen munkában található magyar megoldási lehetôségek - távolabbiak vagy éppen már megléphetốk - a hazai specialitások figyelembevételével kerültek összegyújtésre.

\section{Mit jelent a verseny?}

A piaci múködés normál állapota, hogy a résztvevők mindegyike bővülni akar, nagyobb szeletet szeretne magának. Ez a piac korlátozott lehetôségei miatt óhatatlanul odavezet, hogy a szereplők egymással küzdenek, versenyeznek. A piaci versenyben való sikeres szereplés egyik feltétele, hogy a versenyzó vállalkozás alkalmas legyen az általa kitúzött célok elérésére, egy adott piaci szegmensben egy adott termékkel, szolgáltatással olyan pozíció elérésére, amely a különbözó érdekkörök, stakeholderok elégedettségét hosszú távon kivívja.

\section{Melyek a versenyképesség a fö dimenziói?}

Az operational management tudományterület 4 fố dimenziót jelöl meg, amely meghatározza egy adott vállalkozás versenyképességét: a termék/szolgáltatás minôsége, a vállalati folyamatok komplexitása, az ár és a flexibilitás (Krajewsky- Ritzman: 2005.)

Ha kibontjuk ezeket a dimenziókat, és részletesebben elemezzük azokat, akkor e területen tíz olyan vállalatjellemzót tudunk azonosítani, amelyek mérhetők, összehasonlíthatók, vizsgálhatók:

- érzékenység,

- rugalmasság,

- technikai felkészültség,

- szervezóképesség,

- rendszerszemlélet, irányítás,

- munka- és minőségi fegyelem,

- alkotó légkör,

- pénzügyi stabilitás - tartalékforrásokkal,

- vállalakozó szellemú vezetés,

- globális kitekintés (Hoványi, 2006).

\section{Mit jelentenek ezek a vállalatok szempontjából?}

\section{- Érzékenység}

$\mathrm{Az}$ érzékenység a piac változásainak észlelése, vizsgálata, a trendek jó becslése. Mára a hagyományos versenykörnyezet elemzése (STEP: szociológiai, technológiai, gazdasági és politikai) kiegészült a jogi, környezetgazdálkodási és képzési környezet elemzésével (STEEPLE).

\section{- Rugalmasság}

A rugalmasság a piaci változásokra való gyors, helyes reagálás képessége. Fontos a fejlesztói környezet elemzése (Ward2), a különböző fejlettségú országok fejlesztéseinek helyzetelemzése az adott piacon. 


\section{- Technikai felkészülltség}

Emellé társul a saját lehetôségek felmérése (SWOT: erősségek, gyengeségek, lehetőségek, veszélyek) a jelenben, a várható jövôben, sốt a versenytársak reakcióinak valószínúsítése mellett. Ha egy cég követô taktikát folytat, elóbb-utóbb lemarad. Elébe kell menni a holnap, a versenytársak fejlesztéseinek.

\section{- Szervezóképesség}

A vállalakozások általában kevés eróforrással rendelkeznek. Ezért nagyon fontos, hogy a kevéssel úgy gazdálkodjanak, hogy az elég legyen. Ennek alapfeltétele a magas szintú szervezóképesség, a szervezési módszerek rugalmas, változatos és hatásos alkalmazásai.

\section{- Rendszerszemlélet, irányítás}

Tisztában kell lennie minden vezetônek azzal, hogy bármely utasítása, döntése, gondolata egy sor más területen is hatni fog, mint ahová ố szánta. Minden mindennel összefügg. Ezért a célok meghatározásánál, a döntések meghozatala előtt a várható következményekról a feladathoz illeszkedô mértékben hatástanulmányt (nem kell szükségszerúen komoly elemzéseknek lenni) kell végezni, mit, hogyan, mikor fog befolyásolni egy adott, megváltoztatott tevékenység.

\section{- Munka- és minóségi fegyelem}

A TQM (Total Quality Management) elveit, elméletét alkalmazva segíthet egy vállalkozás piaci szereplését megalapozni. Versenyképtelen termékkel nem lehet a piacon megjelenni, tartósan jelen lenni. A versenyképesség mindig az adott piac lehetôségeihez képest, az ár és a hozzátartozó elvárások fényében határozható meg.

\section{- Alkotó légkör}

$\mathrm{Az}$ iparág jellemző tendenciáit, fejlesztéseit követni kell, sốt megelőzni. Ehhez olyan környezetre van szükség, ahol a munkatársak elmondják, elmondhatják ötleteiket, bekapcsolódhatnak az iparágat meghatározó tudományos folyamatokba, profitálhatnak azokból. A vállalati kultúrába beépül a szabad információáramlás - minden irányban.

\section{-Pénzügyi stabilitás - tartalékforrásokkal}

A likviditás, a szükséges fejlesztések finanszírozása, a vagyon- és hitelállomány egyensúlya, az eladósodás kívánatos mérték alatt tartása alapkövetelmény egy vállalkozás múködésének biztosításához.

\section{- Vállalkozó szellemú vezetés}

A vezetés lanyhasága, az egészséges újítási szándék nélkül vegetáló cég nem életképes. A többiek hamar túllépnek rajta, termékei, szolgáltatásai elavulnak, eladhatatlanokká válnak. Ez azonban nem vezethet a vezetốk hazardírozásához. Kicentizett finanszírozás mellett nagyon meg kell gondolni, mire költenek, mibe fektetnek be.

\section{- Globális kitekintés}

A versenykörnyezet elemzése a korábbi szúkebb piaci vizsgálódás helyett kiegészül a nemzetközi vonatkozásokkal is. A STEEPLE elemzéseit nemcsak a hazai környezetre kell elvégezni, hanem a külföldi piacokon is, valamint vizsgálandó a globális környezet hatása (hatásláncok) is (Hoványi, 2006).

\section{Hol áll ma a MÁV SZÜ? Mi jellemezi a versenyké- pesség dimenzióiban múködését?}

\section{- Érzékenység}

A személyszállítás 2 . ábrán látható folyamatai egy fốigazgatói előadáson, 2003-ban kerültek bemutatásra.

\section{2. ábra}

A személyszállitás folyamata

Forrás: a MÁV ZR. Múködési és Szervezeti Szabályzata, 2004.

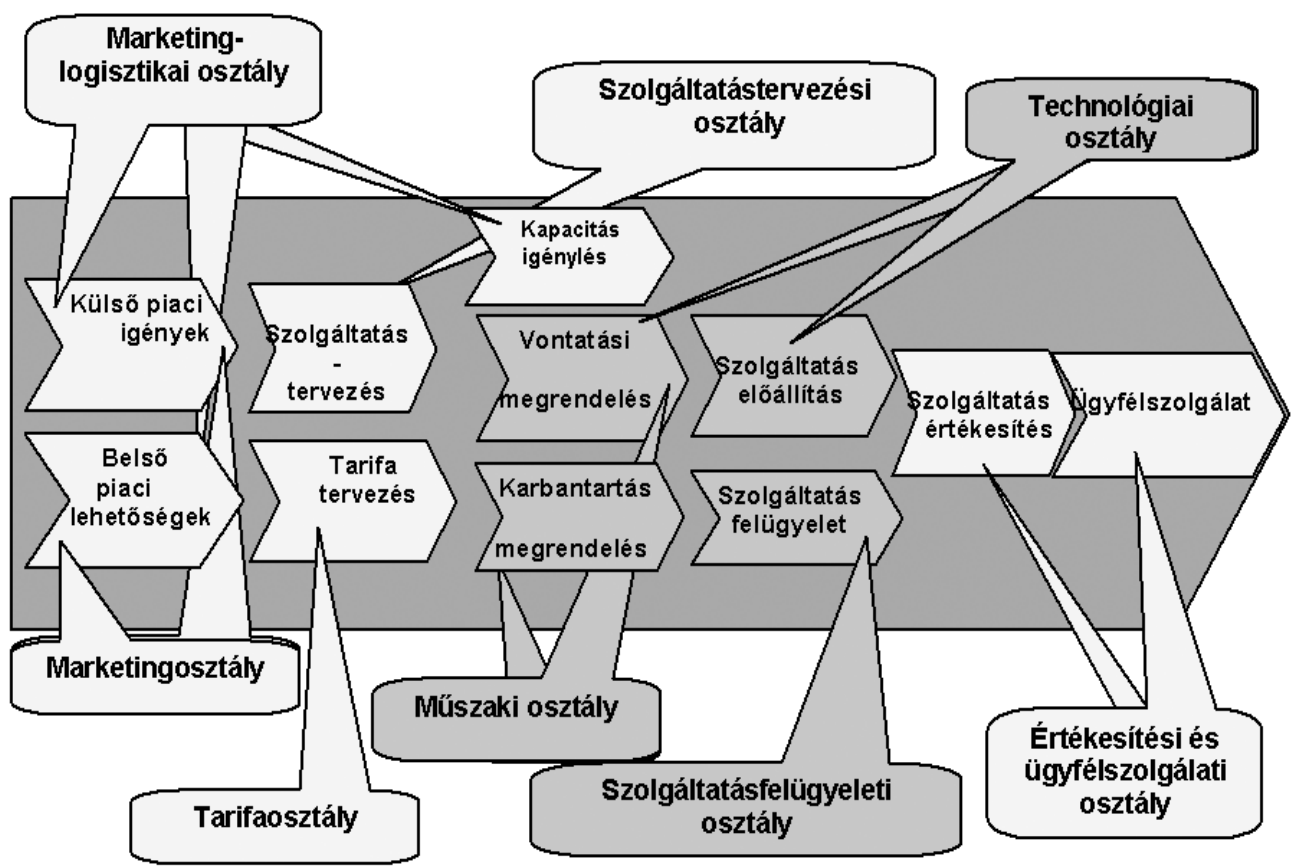


Mint látható, akkor nagy hangsúlyt fektettek a piac megismerésére. Azóta megszúnt a Marketing-logisztikai osztály, a Tarifaosztály integrálódott a Technológiai osztályba, a Szolgáltatástervezési osztály a kék színú területre, azaz az Üzemeltetési főosztályba került. Ezzel mind létszámában, mind felelôsségében lecsökkent a piac megismerésének kérdése. Gyakorlatilag egy fó foglalkozik a nemzetközi piacok megismerésével, egy másik pedig a globalizációs folyamatok kihívásaival (nemzetközi igények, elvárások, integrációs elképzelések elemzése). A marketing, kis túlzással, kimerül az akciózásban.

A jegyek - néhány kivétellel - övezetesek, nem lehet azokból következtetni az útirányra, a használt vonatra. A bérletek ugyan desztinációsak, de senki nem követi a tényleges felhasználásukat sem gyakoriság, sem vonatszám szerint. A díjmentes utazások jellemzói (65 éven felüliek, 6 év alattiak, vasutasok és családtagjaik stb.) egyáltalán nem ismertek.

Saját piackutatásokra van ugyan törekvés, de az évente 1-2 alkalommal 1 héten át tartó, a jegyvizsgálók által becsült és a vezénylók által rögzített foglaltsági adatok pontossága nagyon megkérdőjelezhetô. Nemcsak a nem szeretem munkavégzés, de a saját egyéni vagy kisközösségi érdekek is befolyásolják annak valóságtartalmát.

Az üzletágnak nincs elég pénze ahhoz, hogy a napok minden időszakát, a hónapok, hetek különböző napjait, az éves szezonalitást alaposan elemeztesse, reprezentatív mintákon független piackutatókkal felméresse, sôt azt folyamatosan kövesse. Egyetlen igazán jó piacjelzó van ma a MÁV-nál, az utasok visszajelzései: panaszok, tömegkommunikációs jelzések, bevételi mutatók. Ezek azonban már esố után köpönyeg, így nem lehet igazán piacérzékeny a vállalat.

\section{- Rugalmasság}

Ha a MÁV SZÜ nem ismeri jól a piacát, a várható trendeket, nem is lehet rugalmas. Nincs viszonyítási alapja erre. Egy utat jár ma a vezetôség, a túzoltás útját. Ha valahol nagyon nagy a felháborodás - akár a menetrenddel, akár a technika múszaki állapotával kapcsolatban, akkor oda átcsoportosít, erőforrást allokál.

Stratégia szintjén elhangzott ugyan a piac szegmentálásának igénye és az ahhoz való alkalmazkodás, de a szegmensek nem pontosan definiáltak, nincsenek a valós igényekhez igazítva, és rendszeresen változtatják azokat - előzetes hatáselemzések nélkül.

A piac ismeretlen mozgása, trendjei mellett a használt eszközök hosszú távú befektetései is akadályozzák a rugalmas múködést. Az elkészített stratégia középtávú (2010-ig szól, 2015-ös kitekintéssel), az eszközök viszont (gördülőállomány, állomásépületek, de még a szoftverek is, amit a MÁV jelenleg 15-20 évig használ) hosszú távú tervezést igényelnének. Ráadásul a stratégiák elkészítésének hatalmas erôforrásait egyszeri beruházásként, nagy erőfeszítésnek érzékeli a cég, így azokat szent tehénként kezeli, hozzájuk nem nyúl. Pedig a megfogalmazott feltételrendszerek általában már a kiindulási idôpontban nem teljesülnek.

\section{- Technikai felkészültség}

E tanulmányban nem térek ki részletesen a pálya és az állomások állapotára, hiszen azok nem a SZÜ felelősségi körébe tartozó eszközök. A SZÜ technikai színvonalának általános állapotára csak két terület jellemzói hadd álljanak itt!

Az egyik a jármúvek állapota. A SZÜ felelôsségi körébe utalták - 3 évvel ezelőtt - a vasúti személyszállító kocsikat és a motorvonatokat. Ismeretesek a sajtóból is a motorkocsi tenderek kálváriái, és a felújításokra szánható pénzeszközök folyamatos csökkentése. Az 12 éven belül várható liberalizációban, amennyiben eléri a MÁV-ot, ezekkel az eszközökkel még kelet-európai színtéren sem tud versenyezni. A személykocsik átlagéletkora megközelíti a 30 évet, a nemdolgozó kocsik aránya pedig lassan az egyharmadot.

A másik az informatika területe. Bár nagy erófeszítések történnek az informatikai eszközök és alkalmazások fejlesztésére, azok állapotára jellemzó, hogy a pénztáraknak csak egyötödében van pénztárgép, és ezek is 20 éves technológiával készültek. Az óket felváltó informatikai rendszer tíz éve folyamatosan készül, de még nem lehet tudni, hogy lesz-e egyáltalán a fejlesztésnek valaha vége.

\section{- Szervezóképesség}

A vezetốk visszatérô szlogenje: csak a változás állandó! Ennek megfelelóen folyamatos átszervezésben, költözésben, ki- és beszervezésben telik az üzletág ideje, és erre használódik az ereje.

Mellette azonban a vállalat vezetése döntésképtelen. Látszólagos és felszíni átszervezésekkel próbálja elkerülni az alapos, mindenre és minden szintre kiterjedô változtatásokat.

Egy 160 éves kultúrával rendelkezó vállalatnál nem lehet igazi változtatásokat elérni, ha a szabályozásokat szent tehénként kezelik, ha a 160 év alatt felhalmozódó tudást nem szúrik meg a mai technikai és humán adottságok szúrójén, ha a felsố vezetés nem ért és nem is nagyon akar érteni a vasúti folyamatokhoz, ahhoz a rotációban levő vezetốkhöz tartoznak, akik bármely nagyvállalat élén váratlanul feltúnnek, majd némi zứrzavart okozva odébbállnak. A jelenleg folyó nagyvállalati folyamatprojektnek éppen ezért várhatóan egy pozitív hozadéka lesz: a vállalat vezetôi megismerhetik, hogyan dolgozik a MÁV. 


\section{- Rendszerszemlélet, irányítás}

A legfontosabb lépés, a core competence megválasztása, vállalati szinten nem történt meg. A MÁV - alapító okirata szerint - azért létezik, hogy az állami tulajdonú vasúti pályákat üzemeltesse. Ebben az a lényeg, hogy a MÁV fó́ feladata az üzemeltetés, nem a fenntartás, nem az építés és építtetés.

A SZÜ célja egyértelmúen megfogalmazott: feladata az emberek elszállítása A pontból B pontba. De a modern követelményrendszer integrált közlekedési rendszerekben, multimodális szállításban gondolkodik, azaz a kiindulás az utas kiindulási helye (nem az állomás), érkezési pontja pedig az, ahová tart (és nem az állomás), miközben többféle közlekedési eszközt, módot használ, használhat. A SZÜ azonban úgy készíti stratégiáját, mintha körülötte nem lennének mások, mintha monopolhelyzetben lenne, és feltételezi, hogy az utas az állomáson van, és egy másik állomásra tart.

\section{- Munka- és minóségi fegyelem}

Érdekesek a munkatársak. Élvezik és egyetértenek a félkatonai szervezeti kultúra lebontásával, mégis - fóleg a vezetớk diktatórikus törekvéseik érvényesítésekor -, ha nekik úgy kényelmes, hivatkoznak a szolgálati út betartására, az alá-fölérendeltségi viszonyok szigorú rendjére - még projektmunka, teammunka során is.

A végrehajtásban azonban a munkafegyelem fellazult, az igazi minőségi munka fegyelme talán nem is volt soha.

\section{- Alkotó légkör}

A HR egyáltalán nem áll a helyzet magaslatán. A leépítések teljes létbizonytalansághoz vezettek, a szervilizmus virágzik. Új gondolatok nem születhetnek, a vezetốk - hozzá nem értésük okán - nem mernek felvállalni semmilyen technológiai, múszaki változtatást, a pénztelenség miatt pedig fejlesztéseket sem. Antagonisztikus ellentét feszül a speciális vasúti szakmai tudással rendelkezók és az ettől magukat megtartóztatók között, s mivel az elóbbiek általában a régi vasutasok, az utóbbiak pedig az ifjú szakemberek és a vezetó posztokra valahonnan beesett, beejtőernyőzött, más típusú tudással felvértezettek, a jelenség mint a régi és az új MÁV-osok közötti ellentét jelentkezik. Az újak lenézik, a szerintük megkövesedett, szúklátókörú, fejlődésre képtelen vasutasokat, a vasúti szakemberek pedig nem tekintik partnernek az ezerféle szakkifejezést, utasítást, zsargont nem értóket, a szabályozások útvesztőiben botladozókat. Az ellentét pedig odavezet, hogy az újak nem tudják, a régiek pedig nem engedik a változásokat sikeresen levezényelni.

\section{- Pénzügyi stabilitás - tartalékforrásokkal}

Az állam-MÁV szerződések szabályozzák a vállalat pénzügyi múködését: az állam megrendeli a menet- rendben meghirdetett vonatokat, s mivel hatósági árat szab, valamint szociálpolitikai kedvezményeket adat, a menetjegyek befolyó árbevételein felül fizeti a fogyasztói árkiegészítést, amely a szociális közlekedési juttatás hiányát pótolja, valamint termelői árkiegészítést ad a hatósági ár és a tényleges ár közötti különbözetre. A fogyasztói árkiegészítés késve és hiányosan (az utasszám vitatható becslései miatt), de megérkezik a céghez. A termelói árkiegészítés kifizetése szinte a II. világháború óta nem történt meg, illetve a mindenkori gazdasági helyzet függvényében, a MÁV-ra hátrányos módon valósult meg: a vállalat hitelfelvételét az állam garanciákkal látta el, késóbb pedig rendszeresen konszolidálta azokat. Ez nemcsak a kamatok miatt rossz megoldás, hanem a MÁV-nak a lakossági megítélését is rontja, hiszen a sajtó csak a konszolidáció tényét közli, az okát nem.

Az EU-s szabályozásokra hivatkozva a csatlakozás óta a MÁV egyáltalán nem kapja meg a termelôi árkiegészítést.

\section{- Vállalkozó szellemú vezetés}

A jelenlegi szabályozások nem engednek vállalkozásokat. Minden törekvés megbukik azon, hogy ezt nem teszik lehetôvé a vasútbiztonsági előírások. Nem lehet a pénzügyi nehézségek miatt sem szabadon gondolkodni, de nincs is lehetőségük erre, mert a mindent átszövó „önagyonülésezés” kiöl minden ötletet, mindig van valaki, aki tudja, miért nem lehet valamit megcsinálni.

Rossz a stratégiai megközelítés is, ami alapján olyan társaságok benchmark adatait, eredményeit túzték ki elérendő célnak, amelyek környezete, múltja, lehetôségei a legkisebb mértékben nem hasonlítanak a magyar valóságra (ÖBB, DB). Ez a vállalkozó kedvet megöli.

\section{- Globális kitekintés}

A MÁV 130 évig állam volt az államban. Ettól ma sem tud, és nem akar eltérni. A francia vasút személyszállításban való hegemóniára való törekvése olyan távolinak túnik számára, hogy még vizsgálat tárgyává sem teszik a szövetségben való gondolkodást, pedig lehet, hogy egy ilyen stratégiai szövetség segíthetne a keleteurópai vezető szerep kivívásához. A németek inkább az árufuvarozást akarják kisajátítani, tehát a személyszállításnak valószínúleg nem annyira a német, mint inkább a francia vonalat kellene vizsgálni.

Újra kellene gondolni a stratégiai szövetségeken túl a benchmark releváns merítési körét is.

\section{Hol vannak kitörési pontok?}

A nagy hajók sokkal nehezebben manóvereznek, mint kicsi társaik. E természeti képpel szokták magyarázni a nagy országok, világbirodalmak, nagyvállalatok me- 
revségét. Ám a nagy hajók is gyorsabban fordulnak, ha tudják, milyen eszközöket használhatnak ehhez, és nem csak az utasok tenyerével evezgetnek a hajó egyik oldalán (esetleg mindkettőn egyszerre, hogy még hatástalanabb legyen a történet).

Tekintsük végig a versenyképesség javításának lehetôségeit a nagyon korlátozott lehetôségekkel rendelkezô SZÜ-nél!

Új stratégiát kellene készíteni - az eszközök élettartamával összehasonlítható időtartamra! Nem baj, ha nem színes és mindentudó, de több forgatókönyvvel, hosszabb időtávra (a beruházásokkal összemérhetố idôtávban) gondolkodva, azt a munkakörökig lebontani, határidôzni. És folyamatosan vizsgálni a megvalósulást, az eltérések okait, a változó körülményekhez hozzáigazítani azt. Ehhez ki kell dolgozni a Balanced Scorecard (vagy ahhoz hasonló) mutatószám-rendszert, amely a stratégiai célokat, az idôszaki eredményeket operacionalizálja, mérhetóvé, ellenőrizhetôvé, láthatóvá teszi. Egy komplex mutatószám-rendszert mindenképpen alkalmazni kell a vállalatnál, mivel ma már az egysíkú, csak a pénzügyi mutatókat, elemzéseket használó vezetéssel rendelkezô vállalatok nem versenyképesek (Kaplan - Norton, 2005).

A stratégiának fontos eleme kell, hogy legyen a vállalat(ok) szerkezete, tulajdonviszonyai, beágyazódása a közlekedési piacba, a társadalomba, az EU-s elő́rásoknak megfelelố, de a magyar társadalmi specialitásokat kiszolgáló gazdasági környezet biztosítása.

Újra kellene gondolni, mit vállal fel a cég, és aszerint újraírni az állam-MÁV szerződést!

Nem szabad a nyugati vasutak mutatóihoz hasonlítani a magyar eredményeket! A SWOT-analízisból adódó eredmények (elsôsorban a lehetôségek, veszélyek) alapján kell kiválasztani a benchmark-partnereket (pl. cseh, román, lengyel vasutak). Ezután az eszközöket apróbb lépésekben kell fejleszteni. A MÁV mindig átesik a ló túlsó oldalára: ha meszelni kellene egy állomást, azt elmulasztja, de a teljesen lerobbant, alig használt szolgálati helyeket úgy újítja fel, ha sor kerül rájuk, hogy abból 50 másikat lehetett volna szinten tartani.

A gördülőállománynál is be kell érni az egyszerúbb technikákkal, akár bérelve, lízingelve, örökölve eleinte.

A rendszerszemléletú, multimodális közlekedtetés megköveteli a közlekedési vállalatok stratégiai szövetségeit, sôt ha azt tudjuk, hogy a közepes vállalatok lassan megszúnnek, a vállalatok integrálása is kívánatos. A közlekedési vállalatok másik irányú változtatása is elindult, azaz létrejöhetnek - és az EU-s támogatási politika, valamint a rugalmasság növelése miatt ez cél- szerú is - a KKV-méretú, regionális vállalatok. Ezek életképességét nagyban növeli, ha a központi fixköltségeket nem osztják le rájuk, s csak annyi terhet vállalnak, amelyet elbírnak.

A szabályozásokat elölról fel kellene építeni, logikus rendszerbe szervezni, hogy ne lehessen mögéjük bújva a változtatásokat negligálni.

A MÁV országos méretú, nemzetközi csápokkal rendelkező cég, elképzelhetetlen egy globális beágyazottság nélküli múködtetése. Ezt az EU-csatlakozás és a nemzetközi korridorok magyarországi áthaladása is determinálja. Nem szabad provinciális gondolkodással vezetni a céget!

A vállalaton, üzletágon belül is rendszerben kell gondolkodni! Példaképpen az IT (informatikai terület) fejlesztései, módosításai hadd álljanak itt! Az eddigi autokratikus fejlesztési módszertan (a legerôsebb vezetô eldöntötte, mit, hogyan, kivel fejlesztet) helyett a stratégiai gondolkodás alapján kivitelezett technológia - adatok - IT-kontrolling -vezetés-rendszerek szinergiájában való megvalósítás kell, hogy a középpontban álljon! Ne a hiúság, a mások követése, a reklámokban látottak megvalósítása legyen a középpontban, hanem a vállalat múködéséhez szükséges adatok menedzselése, amely már magával hozza a szükséges alkalmazások installálását, ezek pedig determinálják a szükséges múszaki hátteret.

Amíg nincs megfogalmazva minőségi követelmény a beszállítók, a társüzletágak részére, addig a saját munkavállaló arra hivatkozik, hogy más rontotta el a dolgokat. Ha a feltételek adottak, akkor a megfelelően képzett és motivált, ösztönzött munkaerótól meg kell követelni a fegyelmezett munkát.

Ha egy cégnek nincs erőforrása releváns piackutatásokat végezni, akkor használja mások adatait, és végezzen rajtuk saját elemzéseket. A közlekedési igények meghatározottsága leginkább a társadalom oldaláról adott, változását a társadalmi mozgások determinálják. A KSH, a közvélemény-kutatók ezirányú adatai viszonylag olcsón elérhetốk. A SZÜ-nek fel kell vállalnia, hogy a saját értékesítési és ügyfélszolgálati adatai mellett folyamatosan vizsgálja a társadalmi trendeket. Ehhez csak egy munkatárs kell egy statisztikai elemzó programmal.

A vezetốk autokratikus vezetési stílusát át kell alakítani - képzésekkel, személycserékkel, legfelső szintú példamutatással - munkatársi kapcsolattá, nem alá- és fölérendeltek, rabszolgatartók és rabszolgáik együtt munkálkodásává.

A MÁV a humán tốkéjével egyáltalán nem gazdálkodik. A felhalmozott tudást a megkövült szemlélettel azonosítják, a tanuló szervezetet, a szervezeti dinamiz- 
must a szakmai dilettantizmussal és a korunkban már nem létezô polihisztorsággal keverik.

A humán tốkét múködtetni lehet és kell, például azzal, hogy a tervezóintézetekben felgyưlt gondolatokat felajánlani a piacon, azaz eladni az eddig fiókban tartott, fióknak gyártott, nagy szellemi erốt képviseló tanulmányokat, terveket.

Egy ekkora nagy cégnél, állami tulajdonlás mellett a vállalkozó szellemú vezetés szinte elképzelhetetlen. Kisebb volumenú fejlesztések, újítások azonban kivitelezhetốk lennének, ha a vezetók megbíznának a munkatársaikban (szakértelem híján nem tehetnek mást) és döntésképesek lennének.

Az állam többszáz milliárdos tartozását minden törvényes út segítségével be kell hajtani! Ha kell, bírósághoz fordulva egyszer rendezni kell a folyamatos szerződésszegés következményét.

Milyen lehetne egy intézkedési terv, amely a versenyképesség megvalósítása érdekében született?

1. A jogi keretek tisztázása, egyértelmúvé tétele. Az állam-MÁV szerződés újrakötése, a közszolgálati feladatok pontos definiálása, a finanszírozás újradefiniálása - új küldetés, misszió megfogalmazása, ha kell. (3. ábra)

2. A Gépészeti Üzletág vagy a Pályavasúti Üzletág, az Ingatlangazdálkodás, esetleg a már kiszervezésre került árufuvarozás (MÁV CARGO) esetleges nyereségét a személyszállításba forgatni nem szabad! A legutolsó reform átláthatóvá akarta tenni a vállalat gazdálkodását. Ez részben sikerült. Erre építve már lehet tervezni, de tovább kell menni! Ma a központi költségekbe eldugott költségek fenntartják a keresztfinanszírozásokat.

3. A tulajdonviszonyok rugalmassá tétele (akár banki, de önkormányzati részvétellel is). $\mathrm{Az}$ EU az állami tulajdonú cégek állami finanszírozását tiltja, de az állami feladatokat felvállaló önkormányzati, magántulajdonú vállalatok már kaphatnak költségvetési pénzeket. (4. ábra)

4. A támogatást ki kapja: a vállalat, a tulajdonos, az utas? Nemzetközi példák mutatják a sok- színúséget, amivel a hatóság által méltányosnak ítélt menetjegyárakat a szolgáltatók számára elfogadható költségtérítésekkel harmonizálni lehet. Célszerú lehet válogatni a bevált formák közül.

5. Stratégia készítése és folyamatos követése. Eldönteni, hogy kihez hasonlítsuk magunkat - a benchmarkadatok körének meghatározása.

6. A múködés területének pontos körvonalazása:

a. mi MÁV SZÜ feladata,

b. mit fog hosszú távon fejleszteni, szövetségbe, holdingba vinni,

c. melyekből vonul ki (PPP, outsourcing, önkormányzati tulajdon stb.).

7. A mellékvonalak kezelésének pontosítása:

a. a foóvonalak és a mellékvonalak szétválasztása,

b. a mellékvonalak szétválasztása:

i. megmaradó, amelyet fel kell újítani,

ii. megmarad, szinten tartással,

iii.megmarad, fejlesztik (pl. villamosítással),

iv. a pályát megszüntetik, a vonalat busszal üzemeltetik,

v. a pályát rekultiválják, majd el kell dönteni, hogy a múködtetést saját maga a MÁV SZÜ folytatja, vagy megváltozik az üzemeltetô.

8. Stratégiai szövetségek létrehozása:

a. a MÁV holdingszerú múködésének kialakítása, piacszerú múködés kialakítása a holding vállalatai és a szatellit MÁV-Kft-k között,

\section{3. ábra}

A MÁV átalakításának stratégiája

(Forrás: Boston Consulting Group)

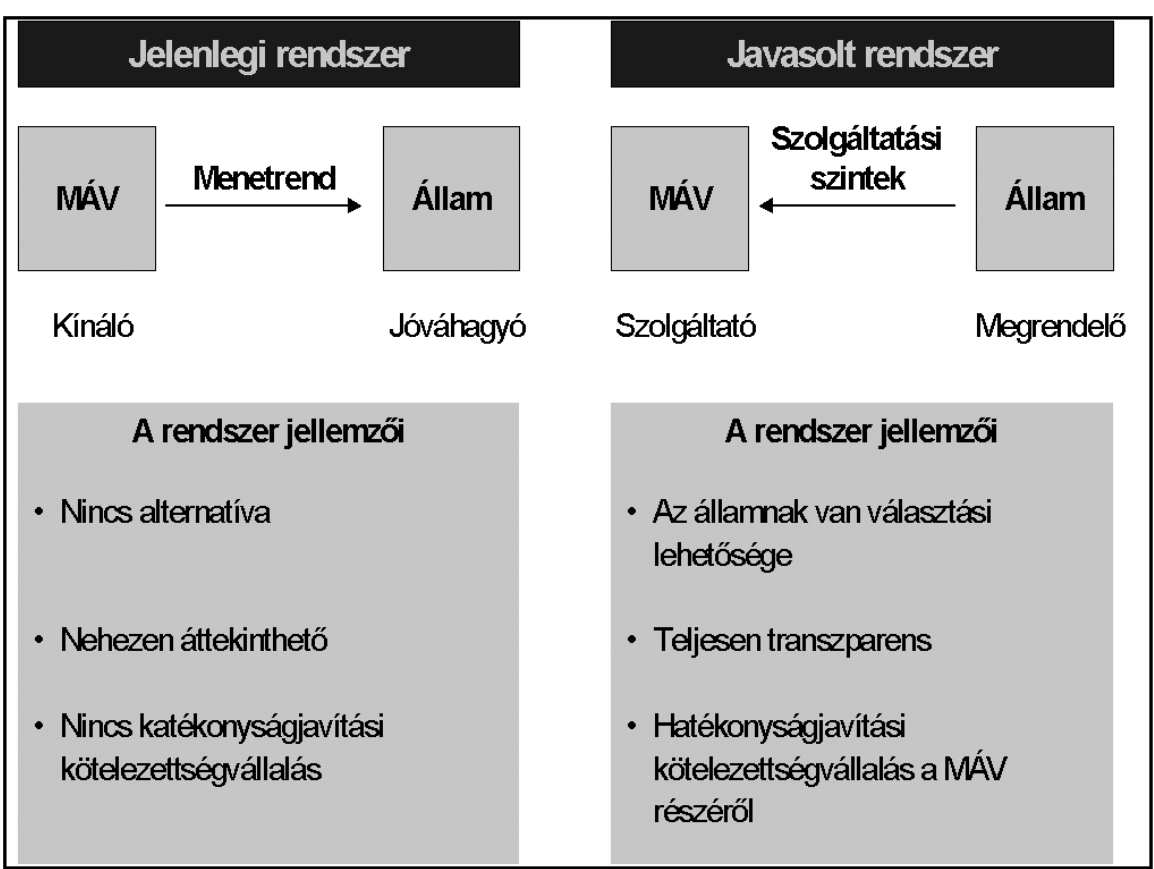




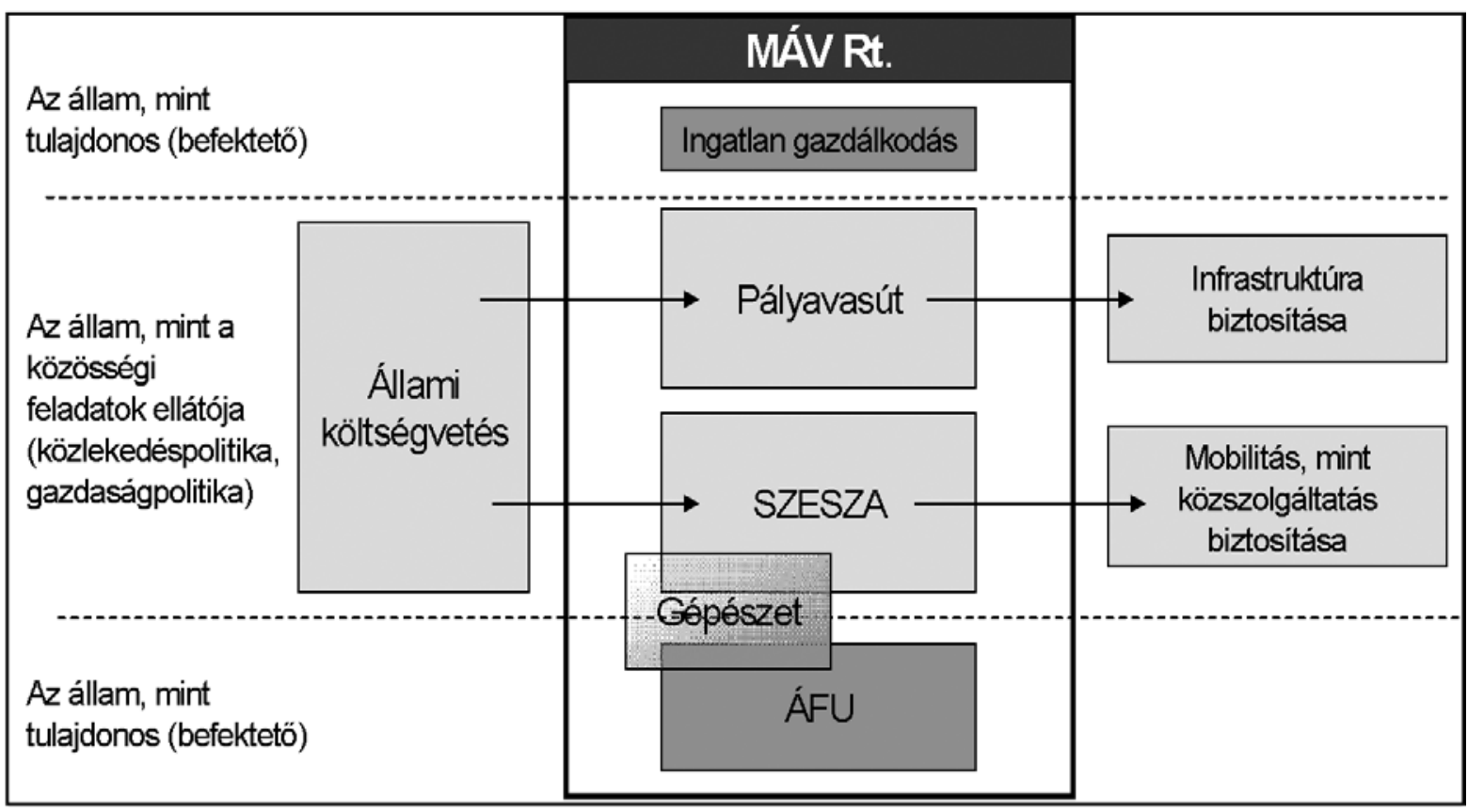

4. ábra

A MÁV tulajdonviszonyai

(Forrás: Boston Counsulting Group)

b. magyar közlekedési vállalatokkal (esetleg holdingszerú múködést kialakítva) - buszvállalatokkal a ráhordás érdekében,

c. külföldi közlekedési vállalatokkal, nemcsak vasúttársaságokkal, kb. 600-800 km-es körzetben (technika bérlése, fejlesztések szinergiája miatt),

d. SLA-k megfogalmazása,

e. egyéb társaságokkal, vállalatokkal (pl. turisztikai, idegenforgalmi, közszolgáltató, társadalmi szervezetek stb.) való szövetség.

9. A vállalati folyamatok azonosítása, redukálása, BPR-ja (Business Process Re-engineering). Mivel a vállalat kisebb reformok tucatjain esett át, és a múködése nem javult, valószínú, hogy csak a folyamatok újjászervezése hozhat gyökeres változást. Ez azonban kockázatos, ezért alapos felkészülést igényel, és a legfelsố szinten eltökéltséget, szabad kezet követel meg.

10. A szervezet újraszervezése, új irányítási rendszer - kommunikáció is! - létrehozása az új vagy megújított folyamatok mentén.

11. A szabályozások rendszerének újradefiniálása, újraírása.

12. Az elmaradt jogos állami kifizetések behajtása.

13. Az államnak mint tulajdonosnak gazdasági érdeke, hogy a vállalata múködóképes és legalább nullszaldós legyen, ezért jogszerú támogatásokkal kell, hogy segítse: a. az élố munka terheinek csökkentésével (adó- és járulékkedvezmények nyújtásával, képzési támogatással,

b. átfogó költségvetési stabilitás biztosításával, azaz azzal, hogy a költségvetésben kiszámítható módon, tartósan követhetô lesz a közszolgáltatások helyzete, finanszírozása,

c. a közvetlen gazdasági szabályozások kedvezô megvalósításával,

d. a célszerú tulajdonosi szerkezet kialakításának támogatása,

e. a vállalati versenyképességet támogató környezeti feltételek biztosítása (humán és reálinfrastruktúra biztosítása, azaz az oktatás és a pályaépítés, -fenntartás tulajdonosi megvalósításával, a múködési önállóság biztosításával) (Chikán, 2006).

14. A szerződésből adódó, előre látható veszteségek fel nem vállalása: pl. a veszteségtermelő folyamatok kiszervezése, államilag finanszírozható feladatokká alakítása.

15. Kereskedelmi szemléletú vállalat létrehozása (marketingkutatások vagy releváns pótlásuk, CRM - ügyfélmenedzselés múködtetése, szerződéskötések egyszerúsítése, speciális szállítási feladatokhoz különleges kocsik biztosítása: a vasúton dolgozó, tanuló utasok számára IT-környezet kialakítása, autószállító kocsik beállítása, fedélzeti pénztárak 
múködtetése: jegyvizsgálóval, mozdonyvezetővel, automata menetjegy-kiadóval, chipkártyás megoldások installálásával stb.).

16. Szolgáltató centrumként való üzemeltetés: az állomásépületek kialakítása az utasok számára hasznos szolgáltatások számára, a vonatokon mozgó szolgáltatások (fittnesz-terem, korrepetálás, fodrász, kávézó, látványpékség, újságos, olvasóterem, szolárium, zuhanyozó, e-fülkék) nyújtása.

16. A biztonság erôsítése (az utazás teljes idôtartama alatt - webkamerákkal, vasútőrökkel, a jegyvizsgálók megfelelő felszerelésével, képzésével).

17. A minôség javítása (pontosság - SLA-kban biztosítékok beépítése a szolgáltatók, társ-üzletágak tevékenysége minôségének biztosítására, kényelem, sorbaállások elkerülése - utasközpontú beszerzések, szolgáltatások tervezése, garanciák biztosítása a nem az ígért minőségú, mennyiségú, határidős szolgáltatás nyújtása esetére) (Brown-Summer, 2000).

18. A környezetvédelmi terület potenciáljának hasznosítása (hulladékhő felhasználása, szeméterômú építése, a vállalat környezetbarát imidzsének felhasználása a stratégiai szövetségek létrehozásában, a versenytársakkal való összehasonlításban).

19. Versenycélok pontosítása, az ellenfelek és gyenge pontjaik azonosítása:

a. az autóbusz-társaságokkal szemben (a vasút jobb a távolsági, nemzetközi közlekedésben - kényelemben, megbízhatóságban, árban),

b. fapadosok repülótársaságokkal szemben - 600800 km-es körzetben (a vasút jobb a reptéri illeték, a repülôterek és a célhelyek közötti transzferek ideje, a szállodaköltség eliminálása okán),

c. a vasút környezetbarát múk ödésének biztosítása, versenyelônyként való érvényesítése (környezetvédelmi stratégia és múködtetés).

20. A HR-rendszerek outsourcingja - enélkül a jelenlegi munkamódszerek nem építhetốk le és át.

21. A szakmák, képzések újradefiniálása (komplex munkakörök és szakmák létrehozása).

22. A fejlesztési prioritások definiálása mind múszaki, mind technológiai, mind humán területen.

23. Képzések - vezetối is! -, átképzések, a változások elfogadtatása érdekében.

24. Új személyszállítási kultúra kialakítása (tudni kell, hogy ez 8-10 évig is tarthat).

\section{Összefoglalás}

Mivel nem láthatók a világban sehol a vasúti szállítás megsemmisítésének nyomai, s úgy túnik, nemcsak verbális óhaj a vasúti szállítás megtartása, fel kell készülni a vasútvállalatoknak a hatékony, lehetóleg nyereséges üzletmenet kialakítására.

Ehhez tanulmányozni kell a vasúti folyamatokat, elemezni kell hol, melyik tevékenységeknél keletkeznek a bevételt meghaladó költségek. Ezek után a vállalati érdek azt kívánja, hogy ezeket a tevékenységeket szüntessék meg, szervezzék át vagy ki. A dolgozat néhány kitörési pontot tartalmaz. Természetesen nagyon sok további lehetőség is van, amelyek segíthetnének. Ami nem visz elóbbre, az a tétlenség, a változatlanság, a szervezet állandó átalakítása a folyamatok merevsége mellett, a hibás benchmarking.

A MÁV SZÜ tapasztalatai - mint az állatorvosi ló esetében - hasznosíthatók minden vállalatnál, ahol problémák vannak. Csak meg kell találni az azonossági, hasonlósági pontokat, a megoldási javaslatok közül az illeszthetốt. Természetesen, a körülmények ismeretének hiányában, mint minden szakirodalom, csak ajánlásokat adhatunk. Ezekból kiindulva, az ötleteket alkalmazva, továbbfejlesztve, átalakítva lehet az egyedi problémákat orvosolni.

\section{Felhasznált irodalom}

1. Boston Consulting Group (2003): A magyar vasúti közlekedés EU-konform rendszerének kialakitása, a Magyar Államvasutak Rt. gazdálkodási reformja - előterjesztés a Gazdasági és Közlekedési Minisztérium Kollégiuma részére - Boston Consulting Group

2. Brown, M. - Summer. R. (2000): Railways face disaster if they fail to change, IRJ, April

3. СhiкÁn Attila (2006): A kulcsfontosságú versenyképesség, Magyar Hírlap, május 10.

4. Chikán Attila, Czakó Erzsébet, Zoltayné Paprika Zita (szerk.) (2002): Vállalati versenyképesség a globalizálódó magyar gazdaságban, szerk. Chikán Attila, Czakó Erzsébet, Zoltayné Paprika Zita, Akadémiai K., Budapest

5. Dumont, F. (2001): RFF-SNCF. Qu'a changè la rêforme de 1997? - La Vie du Rail, 2001. Sept.

6. Gorbunows, A. (2000): Die Lettische Eisenbahn Bindeglied zwischen Ost und West Z. OSShD, 3. sz.

7. HováNYI GÁBOR (2006): Vállalatirányítás és menedzselés (A Pécsi Tudományegyetemen tartott előadás szerkesztett szövege) www.hovanyig.hu

8. Kaplan, Robert S - Norton, David P. (2005): The Balanced Scorecard: Measures That Drive Performance, July-August, HBR

9. Kaspar, C. (2000): Schweiz: Die Bahnreform nimmt Gestalt, Internationales Verkehrswesen, 7/8. sz.

10. Krajewsky J. L. - Ritzman L. P. (2005): Operations Management, 7th Edition, Addison - Wesley MÁV ZRt. honlap, www.mav.hu 